\title{
Effect of oceanographic features on fine-scale foraging movements of bottlenose dolphins
}

\author{
Helen Bailey ${ }^{1,2, *}$, Paul Thompson ${ }^{1}$ \\ ${ }^{1}$ University of Aberdeen, Institute of Biological \& Environmental Sciences, Lighthouse Field Station, Cromarty, \\ Ross-shire IV11 8YJ, UK
}

${ }^{2}$ Present address: Chesapeake Biological Laboratory, University of Maryland Center for Environmental Science, Solomons, Maryland 20688, USA

\begin{abstract}
Physical processes play an important role in structuring predator-prey interactions by influencing the abundance, distribution and behaviour of prey. Many biological hotspots are associated with ocean currents, fronts and eddies, as a result of their predictability as a prey source. In this study, we determined the effect of topography, tidal currents and fronts on the movements and behaviour of a marine top predator, the bottlenose dolphin Tursiops truncatus, within a known foraging area in the Moray Firth, Scotland. Three main fronts were identified and characterised. Dolphins concentrated their search effort in close proximity to these small-scale fronts. Areas with steep seabed gradients were also preferred, but different sites were used depending on the direction of the current, indicating an effect of topography on hydrodynamics and predator-prey interactions. The mean swimming speed over ground for all dolphin tracks $(\mathrm{n}=26)$ was $1.15 \mathrm{~m} \mathrm{~s}^{-1}$, but their mean speed through the water was higher $\left(2.18 \mathrm{~m} \mathrm{~s}^{-1}\right)$. This is close to the most energetically efficient swimming speed for bottlenose dolphins. On average, the dolphins therefore appeared to be expending minimal energy during movement. These results suggest that the interaction between topography and hydrography provided a mechanism for improving foraging success and/or efficiency for the bottlenose dolphin. The narrowness of the channel may concentrate prey and the presence of topographically controlled fronts may further increase the availability of prey, as well as its predictability. Marine predators can focus their foraging efforts on such locations to improve efficiency and reduce energetic costs.
\end{abstract}

KEY WORDS: Physical-biological interactions · Fronts · Tidal currents · Marine mammal · Tursiops truncatus · Foraging behaviour

Resale or republication not permitted without written consent of the publisher

\section{INTRODUCTION}

Studies of marine communities indicate that physical processes play an important role in structuring predator-prey interactions (Sims \& Quayle 1998). On a large scale, highly productive marine ecosystems have been associated with major ocean currents (Palacios et al. 2006) and meso-scale features such as upwellings, eddies and frontal systems (e.g. Polovina et al. 2001, Hyrenbach et al. 2006). Fronts and eddies have also been found to aggregate prey and attract top predators on finer scales (Hunt et al. 1998, Jahncke et al. 2005a). Since human developments frequently occur within a few kilometres of the shore, it is important that we have a better understanding of physical-biological coupling processes close to the coast so that appropriate management advice can be given for environmental assessments and protected areas.

Ocean and tidal currents can play a strong role in influencing animal movements (Luschi et al. 2003, Campagna et al. 2006). They can act as an aid or hindrance to travel. A measure of an animal's speed over ground, therefore, does not always give an accurate representation of the speed, direction or amount of energy the animal is expending during swimming. Values of speed relative to the water, particularly at 
finer scales, are rarely calculated as they require concurrent measurements of current speed and direction (Gaspar et al. 2006). There is some evidence from turtle tracks that the influence of currents depends on the turtle's momentary behaviour and location of residence (Bentivegna et al. 2007). Finer scale tracking using GPS tags on green turtles in a foraging area revealed that tides were an important determinant of movement and activity patterns (Brooks et al. 2009). These turtles generally remained within the centre of channels where there were the fastest currents, but it is unknown whether the turtles were entrained here or actively steered themselves to this location.

Complex coastal topographies, such as islands, headlands and channels, can modify current patterns to create small-scale eddies and fronts (Wolanski \& Hamner 1988, Johnston \& Read 2007). This can influence the availability of nutrients, retention of plankton and aggregation of fish that may attract predators (Simard et al. 2002, McCulloch \& Shanks 2003, Zamon 2003). For example, Coyle et al. (1992) found that murres concentrated over a submarine ridge during ebb tides, where there was a dense aggregation of sound-scattering organisms. The distribution and abundance of different seabird species has also been attributed to distinct marine environments (Jahncke et al. 2005b). Right whale Eubalaena glacialis sighting rates and the abundance of their prey Calanus finmarchicus had a similar periodicity to that of the tide (Baumgartner et al. 2003). In the Moray Firth in Scotland, bottlenose dolphins Tursiops truncatus showed a spatial association with the surface features of a tidal intrusion front within a narrow channel, indicating that it provided enhanced foraging opportunities (Mendes et al. 2002). There are 2 further constricted channels only a few kilometres away from this site that are regularly frequented by dolphins (Wilson et al. 1997). Water depth was a significant factor determining habitat selection in one of these channels (Hastie et al. 2003). Foraging behaviour in the third channel, the entrance to the Inverness Firth, has been identified based on observations of feeding and area-restricted search movements (Bailey \& Thompson 2006). However, the influence of topographic and hydrographic features on foraging behaviour by the dolphins in this channel has not yet been investigated. There are also few studies that have related fine-scale movements of a top marine predator to a detailed description of the hydrographic properties and their variability within a highly dynamic marine coastal environment (Johnston et al. 2005a), or obtained concurrent animal movement and water column information (Ridoux et al. 1997).

This study uses a combination of hydrographic surveys and animal movement data to investigate the effect of fine-scale oceanographic features on bottle- nose dolphins within a known foraging area. The proportion of time dolphins spent in different areas was examined in relation to the topography and their proximity to frontal features. The influence of the tidal and lunar cycles on the dolphins' movement relative to the tidal current speed and direction was also investigated. Finally, a comparison was made between the dolphins' speed over ground and that relative to the water to gain further insight into their foraging strategies.

\section{MATERIALS AND METHODS}

Data collection. Land-based surveys were conducted from a vantage point overlooking the entrance to the Inverness Firth $\left(57^{\circ} 35^{\prime} \mathrm{N}, 4^{\circ} 06^{\prime} \mathrm{W}\right)$ during May to September 2003 and May to July 2004 as described in Bailey \& Thompson (2006). Movement paths of the dolphins were recorded using a theodolite (Leica T460) to measure surfacing locations, which had a mean error of $20.4 \mathrm{~m}$. Dolphin focal group follows were performed during the surveys and the longest tracks from each day, and only those with at least 20 recorded positions, were analysed $(\mathrm{n}=26)$. The mean dolphin group size was 5.5 individuals ( $\mathrm{SD}=2.3$ ). Each separate track was considered an independent unit in the movement analysis (Fig. 1a).

Characterisation of the fronts. The locations of the surface features of the fronts, visible as foam and turbulence lines, were recorded with the theodolite, measuring the end locations and any points of inflection. This was repeated approximately every 20 min during a survey. During a dolphin focal follow, positions of the fronts were taken as regularly as possible between recording dolphin surfacing locations. The locations of sampling stations to study the 3-dimensional structure of the fronts were chosen based on the average position of surface features, calculated from the theodolite data. Measurements were taken from a $6.5 \mathrm{~m}$ rigid inflatable boat using a conductivity, temperature and depth (CTD) probe (SAIV STD-12) and a current meter (Valeport 106). The casts were performed along transects perpendicular to the fronts including end points on either side of the fronts spanning a distance of about $1 \mathrm{~km}$. At each station, the 2 instruments were deployed simultaneously from the boat and lowered to the seabed. They were allowed to acclimatise for $1 \mathrm{~min}$. The CTD was raised at about $0.5 \mathrm{~m} \mathrm{~s}^{-1}$. The current meter was raised $1 \mathrm{~m}$ at $5 \mathrm{~s}$ intervals, as the instrument used an impellor to measure velocity and was sensitive to upwards movement. The time and position of the boat at the start and end of each deployment was recorded so that the movement of the boat could be taken into account in the calculation of the water cur- 

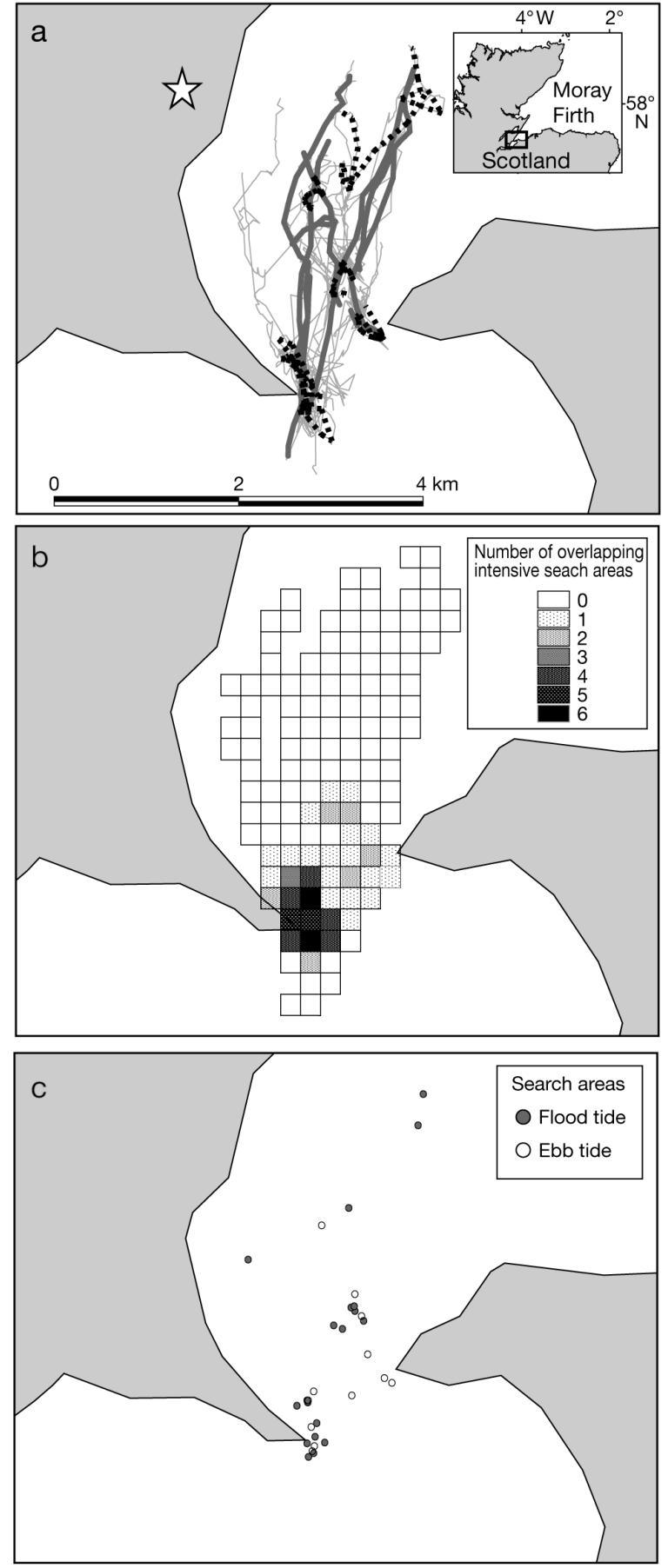

Fig. 1. Tursiops truncatus. (a) Individual bottlenose dolphin tracks $(\mathrm{n}=26)$ with sections of track identified as following a biased random walk (BRW, travelling behaviour, thick grey lines), where they moved less far than predicted by a correlated random walk (patch selection, thick black lines). The white star indicates the observation site. (b) Overlap between the intensively searched areas (determined by first-passage time analysis) within $200 \times 200 \mathrm{~m}$ grid cells; the extent of the grid gives the range over which dolphin positions were recorded (from Bailey \& Thompson 2006). (c) Central points of the intensively searched areas during a flood tide (O) and ebb tide (O) rent speed and direction. Each transect took approximately $1 \mathrm{~h}$ to complete. Deployments were carried out during 3 days within a 1 wk period in August 2003 during a spring tide at the middle of the flood or the ebb cycle, when the tidal velocity was greatest and the fronts were most pronounced.

Temperature, salinity, current speed and direction data were averaged at $1 \mathrm{~m}$ intervals. Contour plots were produced using an inverse distance weighting interpolation function (Surfer, version 7.02). Current speeds were averaged within the top $10 \mathrm{~m}$ (surface currents) and over the whole water column for each station to compare water speeds along the transects. Where current directions spanned over $359^{\circ}$ to $0^{\circ}$, mean current directions were derived using circular methods (Zar 1984).

Association between intensively searched areas and environmental factors. In Bailey \& Thompson (2006), the locations of intensively searched areas for each dolphin track were derived using first-passage time analysis (Fauchald \& Tveraa 2003) and a $200 \times$ $200 \mathrm{~m}$ grid was created showing the number of overlapping search areas within each grid cell (Fig. 1b). In this study, the relationship between the number of search areas and environmental variables within these grid cells was analysed. Bathymetry and seabed sediment data were provided by Scottish Natural Heritage and were derived from data in $25 \times$ $25 \mathrm{~m}$ grid cells. Seabed sediments can act as a proxy for long-term average current speeds and may also indicate prey species habitat preferences (Macleod et al. 2004). Depths were classed at $5 \mathrm{~m}$ intervals (Fig. 2a). Seabed slope was calculated using the 'derive slope' function in ArcView 3.3 (ESRI) and categorised at $0.5^{\circ}$ intervals. Five sediment types were present within the study area, ranging from medium fine sand to cobble and mixed sediment (Fig. 2b). The relationship between the number of search areas and depth, slope and seabed sediment type was tested using a generalised linear model (GLM) with a quasi-Poisson error distribution, to compensate for overdispersion (Crawley 2005), and a log link function (Dobson 2002). Depth and slope were treated as continuous variables and sediment type was given as a categorical variable, with the coarsest sediment cobble and mixed sediment as the reference level. An interaction term between depth and slope was also included in the model. Visual inspection of univariate plots of the response variable and each of the explanatory variables indicated that it was unnecessary to include polynomial terms in the model.

Temporal variation in the location of intensively searched areas was also investigated. Search areas were classified as occurring during a flood or ebb 

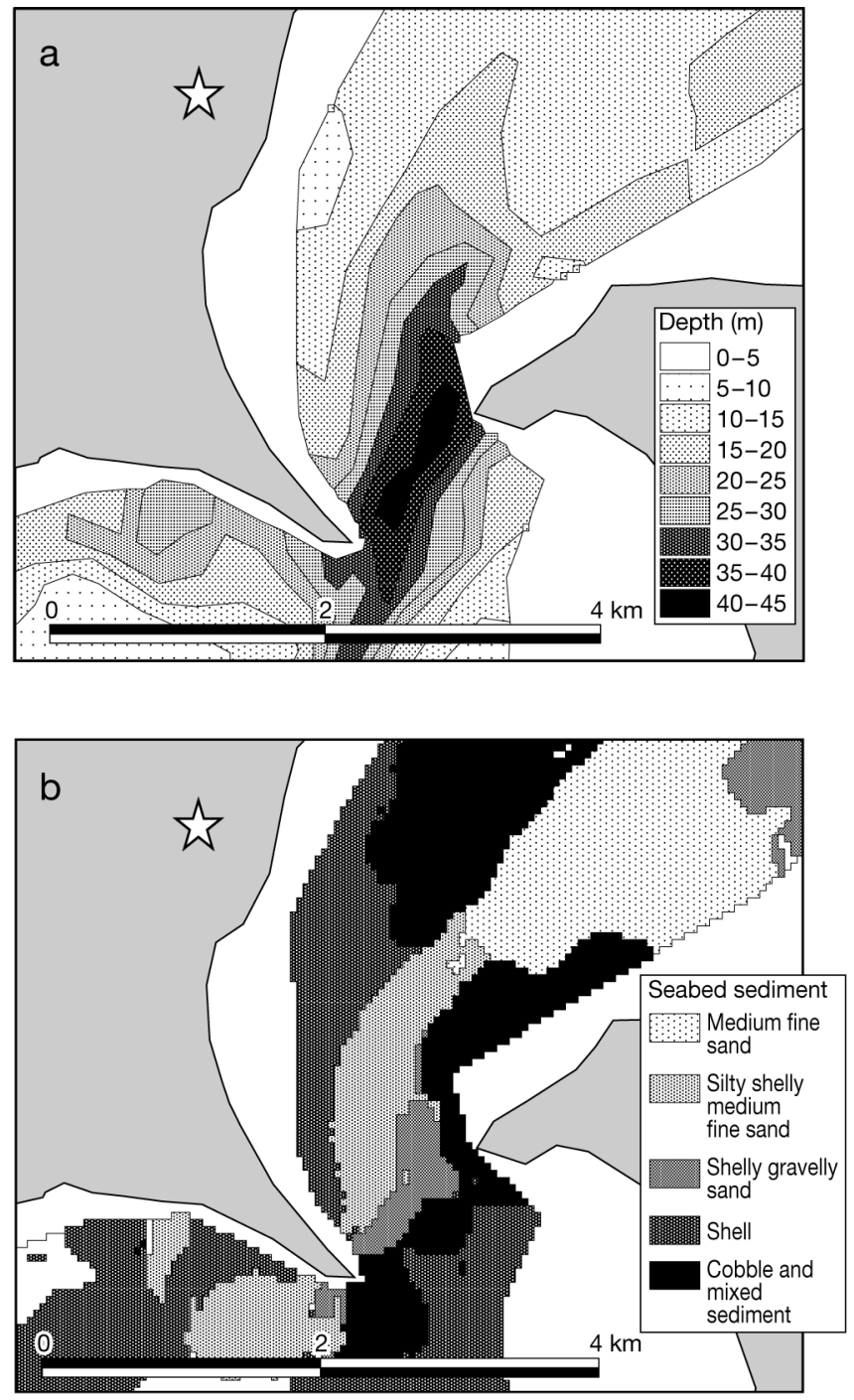

Fig. 2. (a) Depth and (b) seabed sediment type within the study area. The white star indicates the observation site

tide (Fig. 1c), and the number of $200 \times 200 \mathrm{~m}$ grid cells in which they overlapped calculated. A comparison was made between the depth and seabed slope of search areas recorded during flood and ebb tides using Mann-Whitney tests.

Association between dolphins and surface features of the front. Dolphin focal follows were selected that occurred when positions of the fronts had been taken. The location of the front that was closest in time to the dolphin focal group follow was used in the analysis. Areas at $200 \mathrm{~m}$ intervals from the fronts were created using distance buffers in ArcView 3.3. The density of points interpolated at $44 \mathrm{~s}$ intervals along the dolphins' track (the average time between consecutive position recordings) were used to estimate the proportion of time dolphins spent within each distance category from the front. This was compared with the proportion of area available within each distance category (Johnston et al. 2005a). The study area was defined as a polygon containing all dolphin locations, which extended up to $4 \mathrm{~km}$ from the observation site. However, the duration and starting point of each focal follow varied. The area available was therefore calculated by creating a circle centred on the initial position of each focal follow. The radius of the circle was given by the product of the duration of the follow and the average speed from all tracks plus one standard deviation (mean speed $=1.15 \mathrm{~m} \mathrm{~s}^{-1}, \mathrm{SD}=0.57 \mathrm{~m} \mathrm{~s}^{-1}$ ), using the method employed by Allen et al. (2001). If the circle covered a greater area than that defined as the study area, the study area was used as the measure of area available. A Friedman's test was used to compare the proportion of area available with the proportion of time spent during each dolphin track within each $200 \mathrm{~m}$ distance band from the fronts.

Effect of tidal currents on dolphin movements. Water current and dolphin velocities were divided into eastwest $(u)$ and north-south $(v)$ components, which were calculated by:

$$
\begin{aligned}
& u=s \times \sin (d) \\
& v=s \times \cos (d)
\end{aligned}
$$

where $s$ is the speed in $\mathrm{m} \mathrm{s}^{-1}$ and $d$ is the direction in degrees. The tidal currents moved primarily along a north-south axis, being southerly during a flood tide and northerly during an ebb tide. The $v$ speed of the dolphins was compared to the direction of the tidal currents. Dolphin speeds were given as positive if they were in the same direction as the tidal current and negative if they were moving against it. The effect of the lunar cycle (defined as a spring tide within $3 \mathrm{~d}$ either side of the full or new moon and otherwise as a neap tide), the direction of the tidal current (flood or ebb) and the strength of the tidal current (defined as strength 1 within $1 \mathrm{~h}$ of low or high water, strength 2 between 1 and $3 \mathrm{~h}$ after high water, and strength 3 between 3 and $5 \mathrm{~h}$ after high water) on the dolphins' $\mathrm{V}$ speed in relation to the tidal current was examined using a general linear model, having checked that the assumptions were upheld.

Dolphin movements were compared to the correlated random walk (CRW) and biased random walk (BRW) models in Bailey \& Thompson (2006). A comparison was made between dolphin $v$ speeds in relation to the tidal current direction within track sections of 2 contrasting movement types: a BRW (where dolphins moved further than predicted by a CRW, travelling behaviour) and patch selection (where they moved less far than predicted by a CRW). The difference between them was tested using a Mann-Whitney test. 
Comparisons of water current speeds and direction were made with dolphin speeds and route angles over the ground for positions that were recorded at a similar state of the tide (within $1 \mathrm{~h}$ ) and within the area over which current measurements were taken. Hastie et al. (2006) found, by localising calls, that dolphins spent the majority of their time within $10 \mathrm{~m}$ of the surface. The current speed and direction were therefore averaged for the top $10 \mathrm{~m}$ and also over the whole water column. Dolphin swimming speed relative to the water was calculated by subtracting the $u$ and $v$ components of the current speed at the nearest sampling station from the dolphins' $u$ and $v$ speed over ground. Averages of the swimming speed over the bottom (SSB), route angle over the bottom (RA), current speed (CS), current angle (CA), dolphin swimming speed (SSW) and angle (SA) relative to the water were calculated for each separate track (Ridoux et al. 1997). A grand mean was then derived from these averages. Linear regression was used to test for a significant relationship between SSB and SSW.

\section{RESULTS}

\section{Characterisation of fronts}

Within the study area, 3 fronts were regularly identified from visible surface features. Two of these were present during a flood tide (Transect A and B) and one during an ebb tide (Transect C). The location of the sampling stations within the 3 transects, running perpendicular to the fronts, are shown in Fig. 3.

The surface features of the fronts across Transect A and $\mathrm{B}$ were visible between 2 and $5 \mathrm{~h}$ before high water and were most pronounced 3 to $4 \mathrm{~h}$ before high tide. The front occurring during the ebb tide at Transect $\mathrm{C}$ was present between 2 and $4 \mathrm{~h}$ after high water. Measurements of the locations of these fronts showed they could vary by up to $700 \mathrm{~m}$ between days.

Differences in temperature, salinity and the level of stratification occurred along Transect A (Fig. 4). In the shallow area on the east side of the transect, the waters were relatively well-mixed, with only slightly warmer, saltier water in the top $2 \mathrm{~m}$ (Fig. $4 \mathrm{~b}, \mathrm{c}$ ). On the west side of the transect, the waters were more stratified with a relatively well-mixed, less saline surface layer, probably caused by local freshwater inputs. This may have occurred because of the lower current speeds and relatively deep water, which resulted in less tidal mixing (Fig. 4a). A sharp decline in salinity between 10 and $20 \mathrm{~m}$ depth indicated the presence of a halocline, with a deeper, saltier mixed layer below $20 \mathrm{~m}$.

The steep gradient in temperature and salinity between Stns A2 and A4 indicated the location of the front along Transect A (Fig. 4b,c). This is the transition zone between the cooler, saltier water intruding at Stn A5, where there was a fast incoming flow of seawater with the tide, and the more stratified, lower salinity water at Stn A1. The front was characterised by a convergence of water currents, probably from the 2 deep channels approaching from the northwest and northeast (Fig. $2 \mathrm{a})$. These converged into a single channel within the study area, with the fastest current velocity occurring just east of the deepest part of the channel (Fig. 4a).

In contrast, there was a divergence of the water current at the front at Transect B. The single deep channel separates into 2 channels beyond the western peninsula so the main current is split between them (Fig. 2a). The current directions at Stns B1 to B4 were southwest whereas those at Stns B5 and B6 were southeast (Fig. 3). A localised upwelling of deeper water occurred between 100 and $300 \mathrm{~m}$ along the transect, as shown by the shallower depths of the cooler isotherms (Fig. 5b,c). As this cooler water rose towards the surface it was displaced eastwards and westwards by the divergence of the current. It then began to sink as indicated by the downward slope of the isotherms between Stns B3 and B5 and also between Stns B2 and B1. The high current velocities near the deepest part of the channel would draw the water back towards it, completing the circulation (Fig. 5a). On the west side of the transect, close to the peninsula, the water was relatively stratified, particularly within $5 \mathrm{~m}$ of the surface where there was warmer, less saline water. Current speeds were generally much higher and the range of temperature and salinity values was greater along Transect B than Transect A, resulting in stronger horizontal and vertical gradients (Figs. 4 \& 5).

The waters were relatively well-mixed throughout Transect C, with little change in temperature or salinity along the transect (data not shown). The tidal current was generally travelling in a northerly direction, with the ebbing tide (Fig. 6). However, at Stn C1 the currents moved in a southerly direction. The transition in current direction indicated the location of the front. Current speed generally decreased with increasing depth at Transect C (Fig. 6).

\section{Association between intensively searched areas and environmental factors}

The number of search areas within the $200 \times 200 \mathrm{~m}$ grid cells was significantly positively related to the seabed slope (Table 1). More search areas occurred where the seabed slope was steeper. There was no significant relationship with depth, the interaction between depth and slope, or with seabed sediment type (Table 1). 


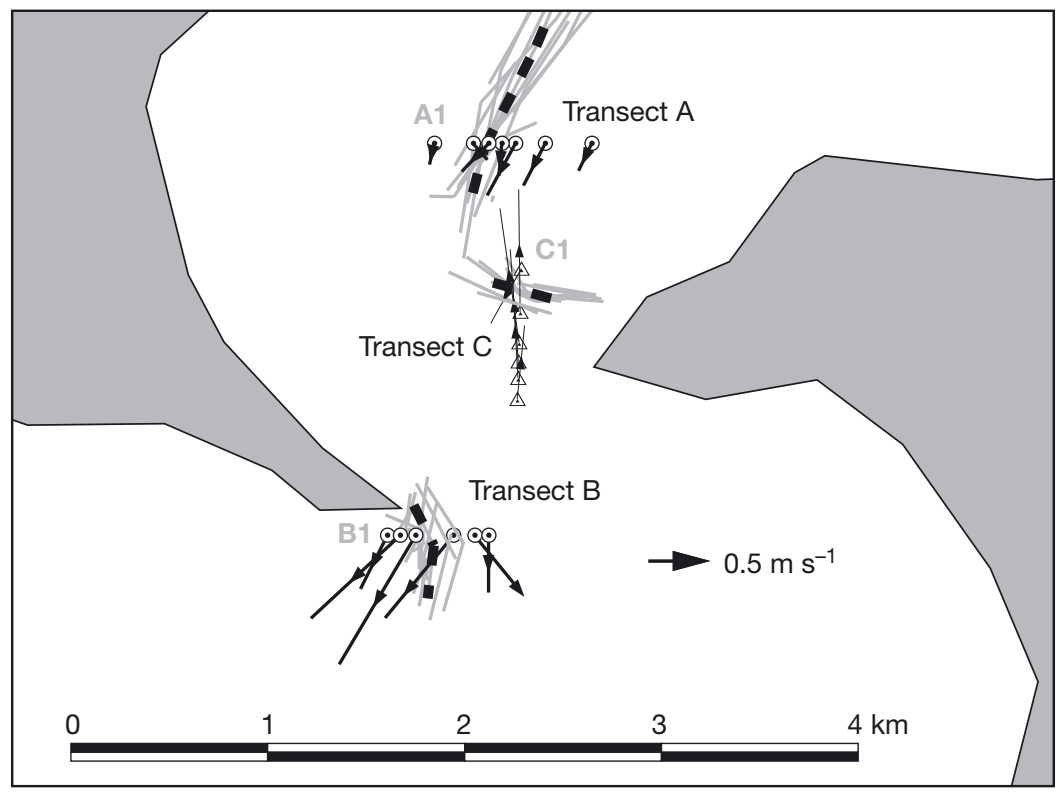

Fig. 3. Hydrographic sampling stations during flood tide $(\odot)$ and ebb tide $(\Delta)$. Positions of the fronts are shown as grey lines and the dashed black line indicates the mean frontal position. Average current directions within $10 \mathrm{~m}$ of the surface are indicated by arrows and mean current speeds by the length of the line. The identifiers A1, B1 and C1 indicate the location of the first sampling station for each transect

There was some overlap between search areas in different tidal states, with $22 \%$ occurring in the same $200 \times 200 \mathrm{~m}$ grid cells during both flood and ebb tides. Most of the overlap occurred off the western peninsula. More intensive searching occurred off the tip of the eastern peninsula during the ebb tide than during the flood (Fig. 1c). However, there was no significant difference in the median depth (Mann-Whitney test: $W=133.0, p=0.234$ ) or seabed slope (Mann-Whitney test: $W=126.5, \mathrm{p}=0.462$ ) between search areas that occurred during the flood or ebb tides.

\section{Association between dolphins and surface features of fronts}

Concurrent measurements of frontal locations were available for 14 dolphin focal groups and these were selected for analysis (Fig. 7). Dolphin positions were recorded up to $3.4 \mathrm{~km}$ from the fronts. The area available for each follow was less than that for the whole study area for only two of the tracks. There was a significant difference in the proportion of time dolphins spent at different distances from the fronts compared to the area available (Friedman test: $S=44.77, \mathrm{df}=$ $16, p<0.001)$. Dolphins spent a higher proportion of time within $400 \mathrm{~m}$ of the fronts than expected, indicating a preference for areas in close proximity to the fronts.

\section{Effect of tidal currents on dolphin movements}

Mean current direction during a flood tide along Transect A was $182.1^{\circ}$ and during an ebb tide at Transect $\mathrm{C}$ was $353.6^{\circ}$ and tidal currents were therefore primarily in a north-south direction. The $v$ speed of the dolphins' movement in relation to this tidal current was not significantly affected by lunar cycle, current direction or strength (general linear model: $F=0.06,1.80$, and 0.21 , $\mathrm{df}=1,1$, and $2, \mathrm{df}_{\text {residual }}=21, \mathrm{p}=0.810$, 0.194 and 0.812 , respectively). There was also no significant difference based on the movement type, defined as travelling (following a BRW) or patch selection (moving less far than predicted by a CRW) (Mann-Whitney test: $W=73.0$, $\mathrm{p}=0.169$ ). The mean dolphin speed in relation to the direction of the tidal currents (where positive indicates movement with the tide) was $0.006 \mathrm{~m} \mathrm{~s}^{-1}$ (SE $=0.113$ ). Since this value is close to zero, it indicates that the dolphins were moving as quickly against the tidal current (given as negative values) as they were moving with it (given as positive values) in a north-south direction.

There were positions from 9 separate tracks for which current data at a similar tidal state and location were also available. These mainly occurred during a flood tide. The average dolphin speed over the bottom (SSB), $1.86 \mathrm{~m} \mathrm{~s}^{-1}$, was slower than the speed relative to the water (SSW), $2.18 \mathrm{~m} \mathrm{~s}^{-1}$. Dolphins therefore appear on average to be moving more frequently against the tidal currents (Table 2). There was a significant positive relationship between SSB and SSW (linear regression: $F=36.90, \mathrm{df}=1,7, \mathrm{p}=0.001$ ), indicating that $\mathrm{SSB}$ increased as SSW increased. There was very little difference between the water current speed and direction averaged over the top $10 \mathrm{~m}\left(0.95 \mathrm{~m} \mathrm{~s}^{-1}\right.$ at $\left.201.97^{\circ}\right)$ and through the whole water column $\left(0.97 \mathrm{~m} \mathrm{~s}^{-1}\right.$ at $203.93^{\circ}$ ).

\section{DISCUSSION}

This study demonstrated that the movements of bottlenose dolphins were influenced by both topography and hydrography. Although there were some differences in the locations of intensively searched areas depending on whether the tide was flooding or ebbing, the topographical characteristics of these areas did not significantly differ. Steep seabed gradients were gen- 

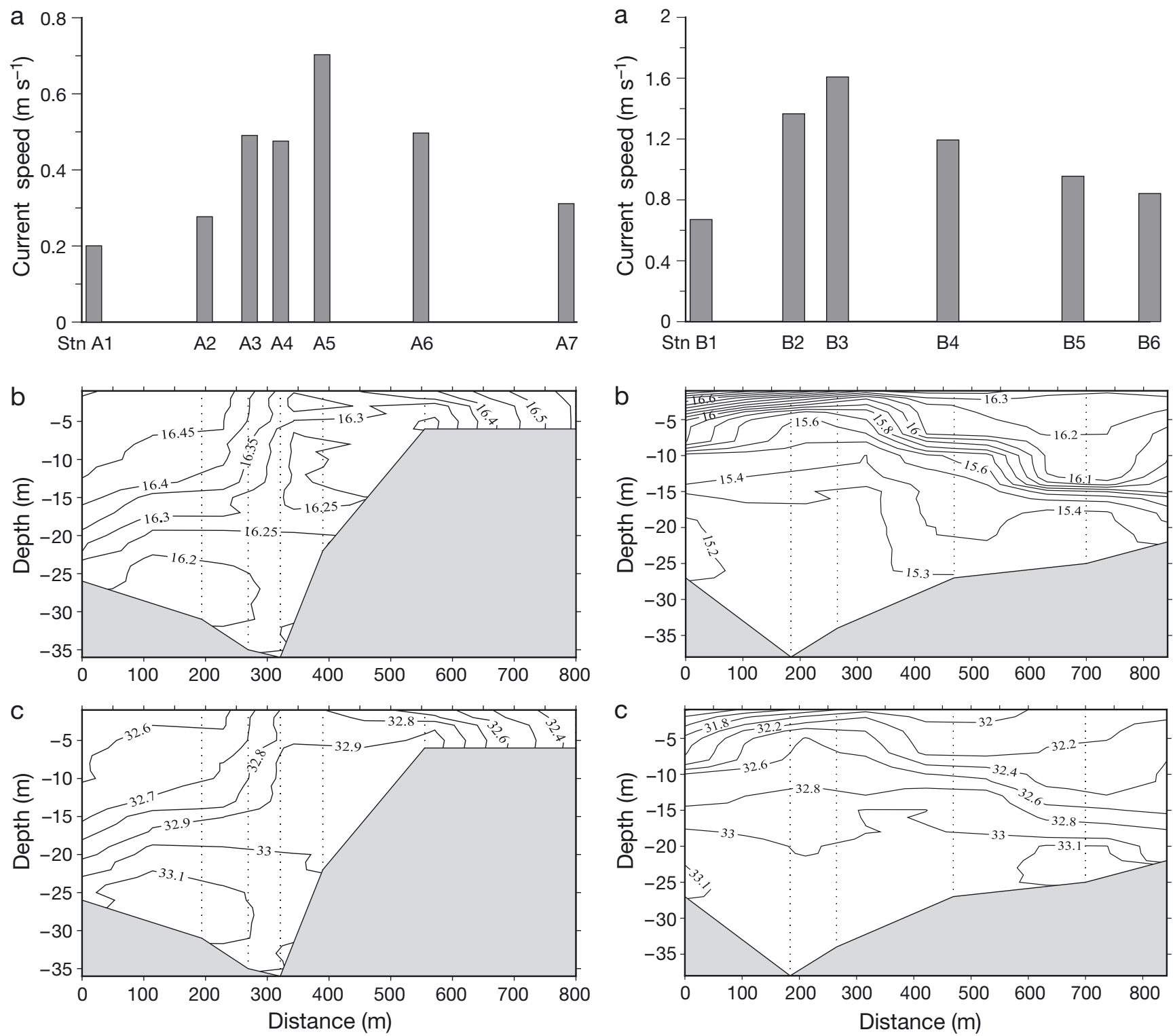

Fig. 4. (a) Mean current speed, (b) temperature $\left({ }^{\circ} \mathrm{C}\right)$ and (c) salinity along Transect $\mathrm{A}$ from west (left) to east (right). The dotted lines in (b) and (c) represent the location of Stns A2 to A6

erally preferred, but the specific location of these sites was dependent on the direction of the water currents (Hunt et al. 1998). As the marine environment is highly dynamic, it is necessary to consider both spatial and temporal aspects of this variability to understand the factors driving animals' distribution and movements.

Bottlenose dolphins concentrated their search effort over steep seabed gradients. More sightings also occurred over steeper slopes at another of the sites where dolphins are regularly seen in the Moray Firth, suggesting that steeper slopes aid in prey detection and capture by providing barriers against which prey could be herded (Hastie et al. 2003). However, we did

Fig. 5. (a) Mean current speed, (b) temperature $\left({ }^{\circ} \mathrm{C}\right)$ and (c) salinity along Transect B from west (left) to east (right). The dotted lines in (b) and (c) represent the location of Stns B2 to B5

not find a significant relationship with seabed sediment type, suggesting that dolphins did not preferentially feed on benthic or demersal prey species associated with particular sediment types. This is in contrast to other marine mammal species around Scotland, such as minke whales (Macleod et al. 2004) and grey seals (McConnell et al. 1999), which are reported to forage predominantly over gravel/sand sediments that are the preferred burrowing habitat of sandeels (Wright et al. 2000, Holland et al. 2005). Sediment type can also indicate long-term average current velocities. The lack of a significant relationship indicates that the dolphins did not select fine-scale areas 


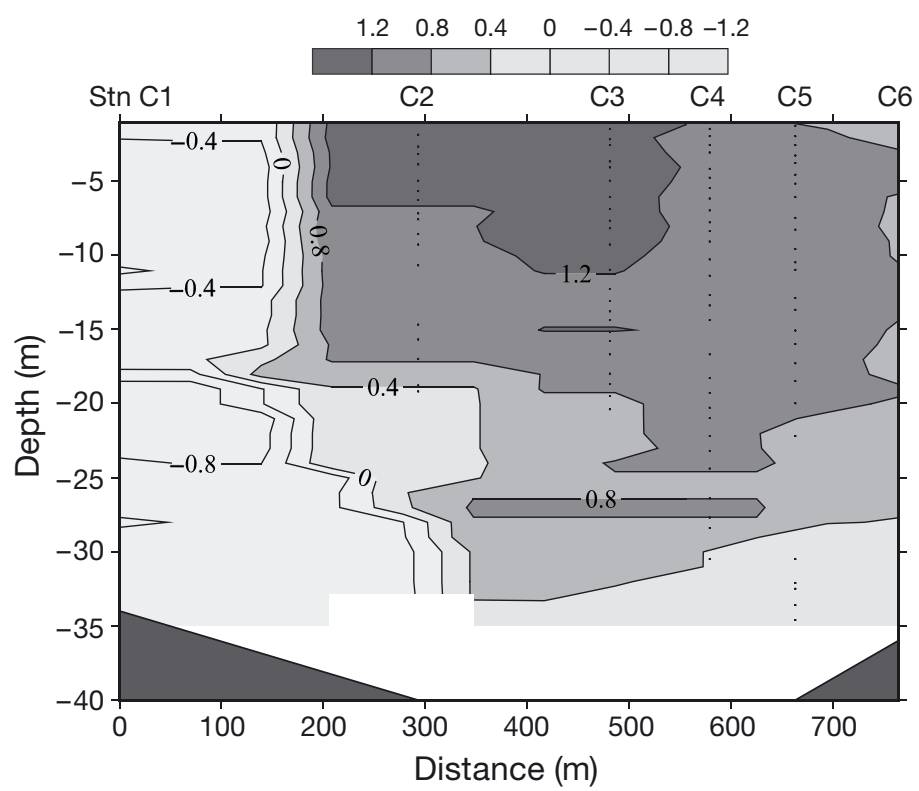

Fig. 6. Contour plot of north-south ( $\mathrm{v}$ ) component of current speed $\left(\mathrm{m} \mathrm{s}^{-1}\right)$ along Transect $\mathrm{C}$ from north (left) to south (right). Positive values indicate northward currents and negative values southward currents. The dotted lines represent the location of Stns C2 to C5

based on their current velocity characteristics. However, current velocities were relatively high throughout the study area, with the finest sediment type being medium fine sand.

Within the study area, 3 main fronts were identified. The weaker stratification and input of freshwater suggested that the fronts characterised in this study were not tidal intrusion fronts as are found in the narrow channel upstream (Mendes et al. 2002). Instead, these fronts were formed as a result of the interaction between the tidal currents and the topography (Wolanski \& Hamner 1988). The spatial displacement of the fronts between days is likely to be caused by variations in the freshwater input, wind forcing and the lunar cycle,

Table 1. Summary results of the generalised linear model analysis of the number of search areas and slope, depth and seabed sediment type. Sediment type was treated as a categorical variable with cobble and mixed sediment as the reference level. ${ }^{*} \mathrm{p}<0.05$

\begin{tabular}{|lrrrr|}
\hline Factor & $\begin{array}{c}\text { Coefficient } \\
\text { estimate }\end{array}$ & SE & $t$-value & $\mathrm{p}$-value \\
\hline Intercept & -1.533 & 0.873 & -1.757 & 0.082 \\
Depth & 0.029 & 0.152 & 0.189 & 0.850 \\
Slope & 0.325 & 0.162 & 2.008 & $0.047^{*}$ \\
Slope $\times$ Depth & -0.002 & 0.027 & -0.069 & 0.946 \\
Sediment type: & & & & \\
Medium fine sand & 1.047 & 0.533 & 1.966 & 0.052 \\
Silty shelly medium fine sand & 0.205 & 0.312 & 0.657 & 0.512 \\
Shelly gravelly sand & 0.123 & 0.386 & 0.319 & 0.750 \\
Shell & 0.199 & 0.409 & 0.487 & 0.627 \\
\hline
\end{tabular}

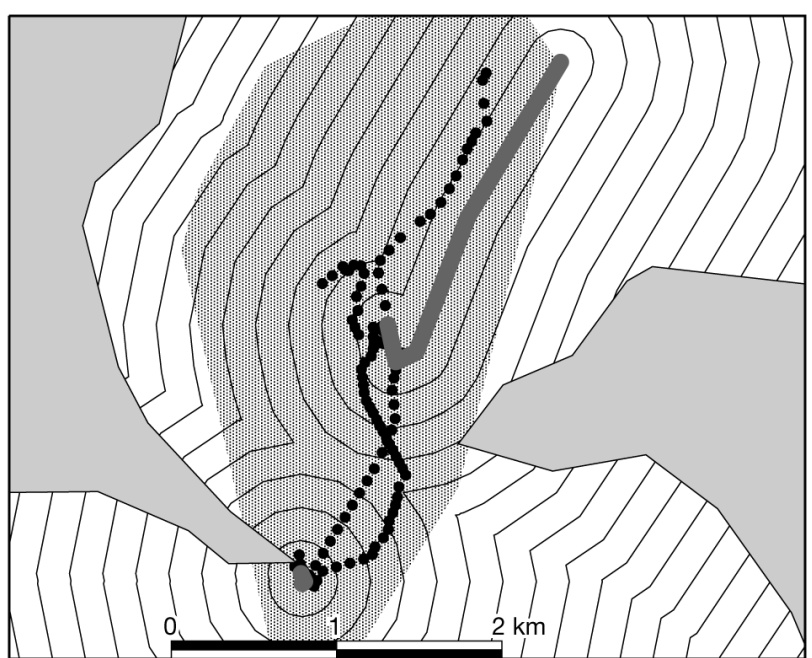

Fig. 7. Tursiops truncatus. An example dolphin track with points interpolated at $44 \mathrm{~s}$ intervals $(\bullet)$. The location of the fronts during this period are shown as grey lines, the surrounding lines indicate distances at $200 \mathrm{~m}$ intervals and the area considered as available habitat during the dolphin track is shaded

which affect the degree of mixing and strength of the horizontal and vertical gradients.

Dolphins concentrated their search effort, known to be indicative of foraging (Bailey \& Thompson 2006), in close proximity to these small-scale fronts. The physical processes occurring at the fronts may have caused a change in the abundance or behaviour of prey, which made it more profitable for the dolphins to feed there. Another type of tidally driven oceanographic feature, an island wake, has also been found to attract marine mammals, including harbour porpoises (Johnston et al. 2005b), and fin and minke whales (Johnston et al. 2005a) in the Bay of Fundy. High vorticity regions such as constricted channels and around headlands can increase encounter rates with prey (Zamon 2001). Within a shallow channel, planktivorous auklets were observed feeding on the upstream side where euphausiids had been upwelled (Hunt et al. 1998). Persistent aggregations of forage fish have also been found that were important for foraging sea lions (Gende \& Sigler 2006). Quantitative measures of prey densities and information on the 3-dimensional movements of dolphins and their prey would greatly aid in understanding how these physical processes act to influence predator-prey interactions.

The fronts observed in this study occurred where there was also a steep seabed gradient, which together with the movement of the tidal currents, were likely to contribute to their formation. This 
Table 2. Tursiops truncatus. Swimming parameters of bottlenose dolphins in the vicinity of current meter measurements. SSB: dolphin swimming speed relative to the seabed, CS: current speed averaged over the top $10 \mathrm{~m}$, SSW: dolphin swimming speed relative to the water, RA: dolphin route angle relative to the seabed, CA: current angle averaged over the top $10 \mathrm{~m}, \mathrm{SA}$ : dolphin swimming angle relative to the current direction

\begin{tabular}{|lccccc|}
\hline Parameter & Mean & SD & SE & Min. & Max. \\
\hline SSB $\left(\mathrm{m} \mathrm{s}^{-1}\right)$ & 1.86 & 1.04 & 0.35 & 0.82 & 3.82 \\
CS $\left(\mathrm{m} \mathrm{s}^{-1}\right)$ & 0.95 & 0.59 & 0.20 & 0.22 & 1.51 \\
SSW $\left(\mathrm{m} \mathrm{s}^{-1}\right)$ & 2.18 & 0.84 & 0.28 & 1.09 & 3.83 \\
RA $\left(^{\circ}\right)$ & 83.15 & 94.91 & 31.64 & 18.04 & 331.96 \\
CA $\left(^{\circ}\right)$ & 201.97 & 45.64 & 15.21 & 145.96 & 354.21 \\
SA $\left(^{\circ}\right)$ & 56.89 & 49.31 & 16.44 & 26.30 & 179.01 \\
\hline
\end{tabular}

makes it difficult to determine whether the steep slopes themselves are influencing the movement of the dolphins, or their proximity to the fronts. Since the fronts only form at particular states of the tide, temporal variability in the movement of the dolphins can be used to identify the dominating factor. The difference in the locations of the intensively searched areas with tidal state indicates that the steepness of the seabed is an important factor influencing the dolphins' movements, but this is in combination with the movement of the tidal currents. Seabed slope alone is therefore unlikely to be the primary factor determining dolphin movements, but plays a key role in influencing the hydrodynamics of the region, which can consequently influence predator-prey interactions.

The north-south $(v)$ component of the dolphins' movement in relation to the tidal currents, which were predominantly in a north (ebb) or south (flood) direction, was not significantly affected by changes in the tidal currents occurring during the lunar or tidal cycles. Although current speeds may reach nearly $2 \mathrm{~m} \mathrm{~s}^{-1}$ during a spring tide (Admiralty Chart 1077), bottlenose dolphins would be capable of swimming at speeds well above this, with maximum speeds of $8.2 \mathrm{~m} \mathrm{~s}^{-1}$ having been recorded (Rohr et al. 2002). The animals also did not appear to alter their behaviour in response to differences in current speed. Dolphin movements following a biased random walk occurred both with and against the tidal currents, indicating that during this travelling mode they did not seem to be using the currents to increase their speed or reduce their energy expenditure.

The mean speed over ground calculated for all 26 tracks was $1.15 \mathrm{~m} \mathrm{~s}^{-1}$, but was higher $\left(1.86 \mathrm{~m} \mathrm{~s}^{-1}\right.$ ) for the sub-sample of positions taken in proximity to the fronts. Higher speeds may be necessary in the pursuit of prey. Using video sonar, Ridoux et al. (1997) calculated a similar mean speed over ground of $1.8 \mathrm{~m} \mathrm{~s}^{-1}$. In our study, the calculated mean swimming speed rel- ative to the water was $2.18 \mathrm{~m} \mathrm{~s}^{-1}$. This very closely matches the value given by Williams et al. (1992), $2.1 \mathrm{~m}$ $\mathrm{s}^{-1}$, as the most energetically efficient swimming speed for bottlenose dolphins at a cost of $1.29 \pm 0.05 \mathrm{~J} \mathrm{~kg}^{-1}$ $\mathrm{m}^{-1}$. On average, the dolphins therefore appeared to be expending minimal energy during movement.

Within the small sample where dolphin positions were recorded at the same state of the tide and location as the water current measurements, the dolphins' movement generally occurred against that of the tidal current. The energetic cost of swimming would consequently be underestimated by only considering the dolphins' speed over ground. Since these measurements occurred in areas near the fronts and where there were a high number of intensively searched areas, this suggests that the dolphins were heading into the tidal current during feeding. This type of behaviour has also been observed at Sanibel Island, Florida (Shane 1990). Thus, dolphins do not seem to be using the tidal currents to reduce energy expenditure and improved foraging success must therefore be balancing these increased costs. Further concurrent measurements of dolphin and current speeds over a larger area and time period would enable further investigation of the dolphins' foraging costs.

Characterising the fronts using a CTD and current meter throughout the water column enabled us to determine how the frontal structure changed with depth. Generally the surface locations of the fronts matched well with those deeper within the water column (Figs. 3 to 6). However, we only had surface positions for the dolphins and therefore cannot confirm that these locations are where they were foraging at depth. Acoustic studies within the Moray Firth that localised calls associated with prey capture events (Janik 2000), indicated feeding behaviour occurred primarily at depths between 20 and $30 \mathrm{~m}$ (Hastie et al. 2006). Obtaining 3-dimensional movements of the dolphins in relation to the tidal currents and frontal characteristics would add greatly to our understanding of their energetic and foraging strategies (Davis et al. 2001, Hindell 2008).

In our analysis, we did not account for the error in the theodolite positions (mean $20 \mathrm{~m}$ ). This will have a small effect on the accuracy of the calculated speed values and hence area use, particularly at locations furthest from the theodolite. However, the error is relatively small so this should not have affected our conclusions. There are now advanced statistical techniques that can be used to account for observation error in tracking data, such as state-space models and particle filters (Jonsen et al. 2005, Tremblay et al. 2009), but these have generally been applied to Argos satellite and geolocation tracking data with much larger errors (several $\mathrm{km}$ ). 
The findings from this study suggest that the interaction between topography and hydrography provide a mechanism for improving foraging success for a marine top predator, the bottlenose dolphin. The narrowness of the channel may concentrate prey and the presence of topographically controlled fronts may further increase the availability of prey, as well as its predictability. Marine predators can focus their foraging efforts on such locations to improve efficiency and reduce energetic costs (Skov \& Prins 2001). Spatial and temporal variation caused by oceanographic processes therefore affects both the distribution and movements of marine predators. This study provides an example of how physical processes at a small scale can influence foraging strategies.

Acknowledgements. Financial support was provided by the Whale and Dolphin Conservation Society and the College of Life Sciences and Medicine at the University of Aberdeen. Thank you to Scottish Natural Heritage and R. Foster-Smith at Envision Mapping Ltd. for providing the high resolution bathymetry and seabed sediment data. Tidal gauge data was kindly provided by K. MacLean at the Inverness Port Authority and the CTD by J. Beaton at the FRS Marine Laboratory, Aberdeen. We are particularly grateful to $\mathrm{T}$. Barton, who provided technical support, and to C. Cadet, M. Campo, C. Clark, J. Foulkes, J.-Y. Lemel, S. Lusseau, A. Villadsgaard and A. Virjee for their assistance during fieldwork. We also thank S. Mendes, B. Scott and 3 anonymous reviewers for their valuable advice.

\section{LITERATURE CITED}

Allen MC, Read AJ, Gaudet J, Sayigh LS (2001) Fine-scale habitat selection of foraging bottlenose dolphins Tursiops truncatus near Clearwater, Florida. Mar Ecol Prog Ser 222: 253-264

Bailey H, Thompson P (2006) Quantitative analysis of bottlenose dolphin movement patterns and their relationship with foraging. J Anim Ecol 75:456-465

Baumgartner MF, Cole TVN, Campbell RG, Teegarden GJ, Durbin EG (2003) Associations between North Atlantic right whales and their prey, Calanus finmarchicus, over diel and tidal time scales. Mar Ecol Prog Ser 264:155-166

Bentivegna F, Valentino F, Falco P, Zambianchi E, Hochscheid S (2007) The relationship between loggerhead turtle (Caretta caretta) movement patterns and Mediterranean currents. Mar Biol 151:1605-1614

Brooks LB, Harvey JT, Nichols WJ (2009) Tidal movements of East Pacific green turtle Chelonia mydas at a foraging area in Baja California Sur, México. Mar Ecol Prog Ser 386:263-274

Campagna C, Piola AR, Marin MR, Lewis M, Fernández T (2006) Southern elephant seal trajectories, fronts and eddies in the Brazil/Malvinas confluence. Deep-Sea Res I 53:1907-1924

> Coyle KO, Hunt GL Jr, Decker MB, Weingartner TJ (1992) Murre foraging, epibenthic sound scattering and tidal advection over a shoal near St. George Island, Bering Sea. Mar Ecol Prog Ser 83:1-14

Crawley MJ (2005) Statistics: an introduction using R. John Wiley \& Sons, Chichester
Davis RW, Fuiman LA, Williams TM, Le Boeuf BJ (2001) Three-dimensional movements and swimming activity of a northern elephant seal. Comp Biochem Physiol 129: $759-770$

Dobson AJ (2002) An introduction to generalized linear models. Chapman \& Hall/CRC, Boca Raton, FL

Fauchald P, Tveraa T (2003) Using first-passage time in the analysis of area-restricted search and habitat selection. Ecology 84:282-288

Gaspar P, Georges JY, Fossette S, Lenoble A, Ferraroli S, Maho Y (2006) Marine animal behaviour: Neglecting ocean currents can lead us up the wrong track. Proc Biol Sci 273:2697-2702

> Gende SM, Sigler MF (2006) Persistence of forage fish 'hot spots' and its association with foraging Steller sea lions (Eumetopias jubatus) in southeast Alaska. Deep-Sea Res II 53:432-441

> Hastie GD, Wilson B, Thompson PM (2003) Fine-scale habitat selection by coastal bottlenose dolphins: application of a new land-based video-montage technique. Can J Zool 81:469-478

> Hastie GD, Wilson B, Thompson PM (2006) Diving deep in a foraging hotspot: acoustic insights into bottlenose dolphin dive depths and feeding behaviour. Mar Biol 148: $1181-1188$

Hindell M (2008) To breathe or not to breathe: optimal strategies for finding prey in a dark, three-dimensional environment. J Anim Ecol 77:847-849

> Holland GJ, Greenstreet SPR, Gibb IM, Fraser HM, Robertson MR (2005) Identifying sandeel Ammodytes marinus sediment habitat preferences in the marine environment. Mar Ecol Prog Ser 303:269-282

Hunt GL Jr, Russell RW, Coyle KO, Weingartner T (1998) Comparative foraging ecology of planktivorous auklets in relation to ocean physics and prey availability. Mar Ecol Prog Ser 167:241-259

> Hyrenbach KD, Veit RR, Weimerskirch H, Hunt GL Jr (2006) Seabird associations with mesoscale eddies: the subtropical Indian Ocean. Mar Ecol Prog Ser 324:271-279

Jahncke J, Coyle KO, Zeeman SI, Kachel NB, Hunt GL Jr (2005a) Distribution of foraging shearwaters relative to inner front of SE Bering Sea. Mar Ecol Prog Ser 305:219-233

Jahncke J, Coyle KO, Hunt GL Jr (2005b) Seabird distribution, abundance and diets in the eastern and central Aleutian Islands. Fish Oceanogr 14(Suppl 1):160-177

Janik VM (2000) Food-related bray calls in wild bottlenose dolphins (Tursiops truncatus). Proc Biol Sci 267:923-927

Johnston DW, Read AJ (2007) Flow-field observations of a tidally driven island wake used by marine mammals in the Bay of Fundy, Canada. Fish Oceanogr 16:422-435

Johnston DW, Thorne LH, Read AJ (2005a) Fin whales Balaenoptera physalus and minke whales Balaenoptera acutorostrata exploit a tidally driven island wake ecosystem in the Bay of Fundy. Mar Ecol Prog Ser 305:287-295

Johnston DW, Westgate AJ, Read AJ (2005b) Effects of finescale oceanographic features on the distribution and movements of harbour porpoises Phocoena phocoena in the Bay of Fundy. Mar Ecol Prog Ser 295:279-293

Jonsen ID, Fleming JM, Myers RA (2005) Robust state-space modeling of animal movement data. Ecology 86:2874-2880

> Luschi P, Hays GC, Papi F (2003) A review of long-distance movements by marine turtles, and the possible role of ocean currents. Oikos 103:293-302

> Macleod K, Fairbairns R, Gill A, Fairbairns B, Gordon J, BlairMyers C, Parsons ECM (2004) Seasonal distribution of minke whales Balaenoptera acutorostrata in relation to physiography and prey off the Isle of Mull, Scotland. Mar 
Ecol Prog Ser 277:263-274

McConnell BJ, Fedak MA, Lovell P, Hammond PS (1999) Movements and foraging areas of grey seals in the North Sea. J Appl Ecol 36:573-590

McCulloch A, Shanks AL (2003) Topographically generated fronts, very nearshore oceanography and the distribution and settlement of mussel larvae and barnacle cyprids. J Plankton Res 25:1427-1439

Mendes S, Turrell W, Lütkebohle T, Thompson P (2002) Influence of the tidal cycle and a tidal intrusion front on the spatio-temporal distribution of coastal bottlenose dolphins. Mar Ecol Prog Ser 239:221-229

Palacios DM, Bograd SJ, Foley DG, Schwing FB (2006) Oceanographic characteristics of biological hot spots in the North Pacific: a remote sensing perspective. Deep-Sea Res II 53:250-269

Polovina JJ, Howell E, Kobayashi DR, Seki MP (2001) The transition zone chlorophyll front, a dynamic global feature defining migration and forage habitat for marine resources. Prog Oceanogr 49:469-483

Ridoux V, Guinet C, Liret C, Creton P, Streenstrup R, Beauplet G (1997) A video sonar as a new tool to study marine mammals in the wild: measurements of dolphin swimming speed. Mar Mamm Sci 13:196-206

Rohr JJ, Fish FE, Gilpatrick JW (2002) Maximum swim speeds of captive and free-ranging delphinids: critical analysis of extraordinary performance. Mar Mamm Sci 18:1-19

Shane SH (1990) Behavior and ecology of the bottlenose dolphin at Sanibel Island, Florida. In: Leatherwood S, Reeves RR (eds) The bottlenose dolphin. Academic Press, San Diego, CA, p 245- 265

Simard Y, Lavoie D, Saucier FJ (2002) Channel head dynamics: capelin (Mallotus villosus) aggregation in the tidally driven upwelling system of the Saguenay-St. Lawrence

Editorial responsibility: Yves Cherel, Villiers-en-Bois, France
Marine Park's whale feeding ground. Can J Fish Aquat Sci 59:197-210

Sims DW, Quayle VA (1998) Selective foraging behaviour of basking sharks on zooplankton in a small-scale front. Nature 393:460-463

Skov H, Prins E (2001) Impact of estuarine fronts on the dispersal of piscivorous birds in the German Bight. Mar Ecol Prog Ser 214:279-287

> Tremblay Y, Robinson PW, Costa DP (2009) A parsimonious approach to modeling animal movement data. PLoS ONE 4:e4711

Williams TM, Friedl WA, Fong ML, Yamada RM, Sedivy P, Haun JE (1992) Travel at low energetic cost by swimming and wave-riding bottlenose dolphins. Nature 355: 821-823

> Wilson B, Thompson PM, Hammond PS (1997) Habitat use by bottlenose dolphins: seasonal distribution and stratified movement patterns in the Moray Firth, Scotland. J Appl Ecol 34:1365-1374

> Wolanski E, Hamner WM (1988) Topographically controlled fronts in the ocean and their biological influence. Science 241:177-181

> Wright PJ, Jensen H, Tuck I (2000) The influence of sediment type on the distribution of the lesser sandeel, Ammodytes marinus. J Sea Res 44:243-256

Zamon JE (2001) Seal predation on salmon and forage fish schools as a function of tidal currents in the San Juan islands, Washington, USA. Fish Oceanogr 10:353-366

Zamon JE (2003) Mixed species aggregations feeding upon herring and sandlance schools in a nearshore archipelago depending on flooding tidal currents. Mar Ecol Prog Ser 261:243-255

Zar JH (1984) Biostatistical analysis. Prentice-Hall International, Englewood Cliffs, NJ

Submitted: August 24, 2009; Accepted: August 24, 2010 Proofs received from author(s): November 4, 2010 